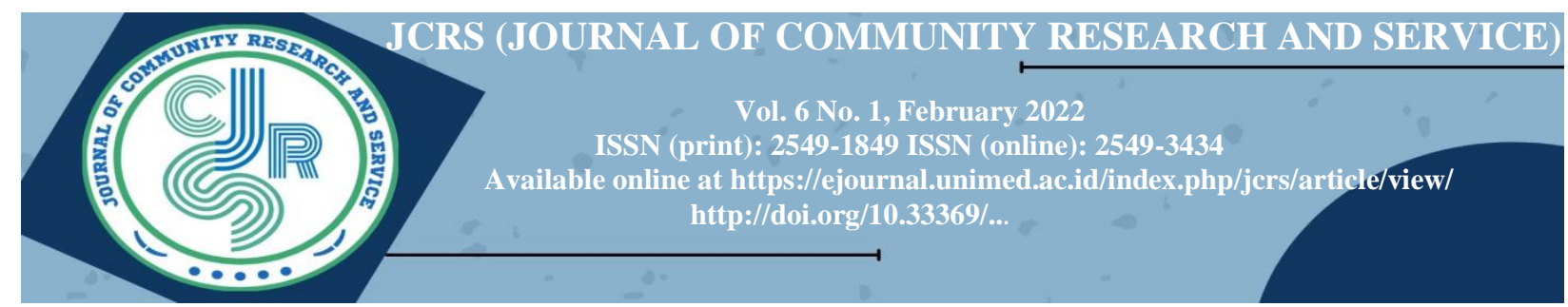

\title{
Analisis Perencanaan Strategi dalam Meningkatkan Pengembangan Usaha Pusat Kegiatan Belajar Masyarakat (PKBM) Rumah Hijau Kabupaten Deli Serdang Sumatera Utara
}

\author{
${ }^{1}$ Rindi Andika, ${ }^{2}$ Erwansyah, ${ }^{3}$ Maya Macia Sari \\ 1,2,3 Manajemen, Universitas Panca Budi, INDONESIA \\ ${ }^{1}$ rindiandika0557@gmail.com
}

\begin{abstract}
The strategic planning of the Community Learning Activity Center (PKBM) is the main function of management in the fields that include planning, organizing, implementing and supervising. This study aims to analyze the improvement in the development of the Green House Community Learning Activity Center (PKBM). The type of research used in this study is a qualitative research with a descriptive type of research that is not intended to test certain hypotheses but to find an overview of the strategic planning of the Community Learning Activity Center (PKBM). The data and information needed in this study were obtained from information from informants, namely people who are considered to know and can be trusted in providing accurate information using two types of data, namely primary data and secondary data. Data collection techniques in this research are direct observation to the research site, in-depth interviews and documentation at the research site. The results of the research show that the implementation of the four management functions of the Green House Community Learning Activity Center (PKBM) when viewed from the planning function is categorized as good because it is structured. The organizing or grouping function is categorized as good, because there are no specific rules, then in the process of implementing the Community Learning Activity Center (PKBM) it is carried out from Monday to Friday, then the supervisory function where during learning activities is supervised by supervisors from the Deli Serdang Education Office.
\end{abstract}

Keywords: Strategy Planning, PKBM, Management Functions

Article history: Received: 01-12-2021; Revised: 10-12-2021; Accepted: 10-02-2022; Available online: 26-02-2022 How to cite this article: Andika, R., Erwansyah, Sari, M.M. (2022) Analisis Perencanaan Strategi dalam Meningkatkan Pengembangan Usaha Pusat Kegiatan Belajar Masyarakat (PKBM) Rumah Hijau Kabupaten Deli Serdang Sumatera Utara. Journal of Community Research and Service, 6(1), xxx-xxx

https://doi.org/10.14710/jcrs.X.X.XxX-XXX

\section{Pendahuluan}

Salah satu aspek terpenting dalam kehidupan adalah pendidikan. Pendidikanlah yang menentukan dan membimbing masa depan dan arah kehidupan. Meski tidak semua orang berpendapat demikian, pendidikan tetap menjadi kebutuhan manusia yang sangat penting. Bakat dan pengalaman diasah dan disempurnakan. Melalui pendidikan juga biasa dijadikan tolak ukur kualitas setiap orang. Salah satu faktor terpenting dalam pembangunan suatu bangsa adalah pendidikan, dan pembangunan nasional suatu negara dapat didukung oleh pendidikan yang berkelanjutan. Orang hanya sebaik sistem pendidikan negaranya, dan warga suatu negara hanya sebaik sistem pendidikan negaranya. Sebuah bisnis diharapkan dapat meningkatkan kualitas sumber daya manusia sehingga warga dapat membantu dalam proses pembangunan. Salah satu solusi untuk meningkatkan kualitas sumber daya manusia di Indonesia adalah melalui pendidikan. Selain pendidikan formal dan nonformal, pendidikan berlangsung di lingkungan keluarga, masyarakat, dan tempat kerja. Undang-undang nomor 20 tahun 2003 tentang Sistem Pendidikan Nasional menyatakan bahwa jalur pendidikan terdiri atas pendidikan formal, nonformal, dan informal JCRS (Journal of Community Research and Service), 6(1), 2022 
yang dapat saling melengkapi. Pasal 16 ayat (4) menyebutkan bahwa satuan pendidikan nonformal terdiri atas forum kursus, forum pelatihan, kelompok belajar, pusat kegiatan belajar masyarakat, dan majelis taklim serta satuan pendidikan yang sejenis.

Satuan pendidikan nonformal yang saat ini berkembang pesat adalah Pusat Kegiatan Belajar Masyarakat (PKBM) yang pada awalnya didirikan di tingkat kecamatan dan kemudian meluas ke setiap desa atau kelurahan. Pusat Kegiatan Belajar Masyarakat (PKBM) telah ditetapkan. oleh rakyat, oleh rakyat dan untuk rakyat. Di Pusat Kegiatan Belajar Masyarakat (PKBM), fungsi utama organisasi adalah memberikan layanan pendidikan kepada masyarakat di luar kelas. Pendirian Pusat Kegiatan Belajar Masyarakat (PKBM) diilhami oleh gagasan Pusat Pembelajaran Masyarakat di berbagai negara maju sejak tahun 1960-an dan dengan adanya pedoman pembelajaran berbasis luas. Pusat Kegiatan Belajar Masyarakat (PKBM) adalah satuan pendidikan yang tidak berlebihan, sebagai tempat belajar dan sumber informasi yang dibentuk oleh masyarakat yang diselaraskan dengan potensi kearifan lokal untuk mengetahui, keterampilan dan sikap. masyarakat dalam bidang ekonomi, sosial dan ekonomi dan budaya [1].

Pusat Kegiatan Belajar Masyarakat (PKBM) berpotensi untuk berdiri sendiri sebagai organisasi yang mandiri karena dibentuk oleh, oleh, dan untuk masyarakat. Namun dalam jangka panjang, sebagian besar Pusat Kegiatan Belajar Masyarakat (PKBM) mampu mandiri dan mengelola peran negara yang semakin berkurang, sehingga dapat berjalan beriringan. bergandengan tangan dengan kemandirian Pusat Kegiatan Belajar Masyarakat (PKBM). Sebagai bagian dari Pusat Kegiatan Belajar Masyarakat (PKBM), otonomi masyarakat akan semakin kokoh.

Pengembangan Pusat Kegiatan Belajar Masyarakat (PKBM) dapat dilakukan dengan beberapa cara, pertama sebagai metode pembelajaran masyarakat yang ditandai dengan (1) mendukung dukungan masyarakat dalam berbagai bentuk; (2) partisipasi masyarakat dalam pengambilan keputusan; (3) kemitraan di mana anggota masyarakat berpartisipasi dalam membangun hubungan yang setara dengan pengelola program; Manfaat lain dari Pusat Kegiatan Belajar Masyarakat (PKBM) adalah berpotensi untuk menyelenggarakan berbagai program pendidikan nonformal dan informal, seperti yang ditujukan untuk pemberdayaan perempuan dan anak serta kecakapan hidup. memberdayakan pendidikan, pendidikan literasi, keterampilan dan vokasi, pendidikan pemerataan dan pendidikan lainnya yang ditujukan untuk meningkatkan potensi siswa. Pusat Kegiatan Belajar Masyarakat dapat digunakan untuk menerapkan prinsip belajar kelompok, di mana suatu komunitas belajar dapat berpartisipasi dalam kegiatan dengan kelompok lain, serta potensi belajar menggunakan pendekatan integratif, di mana proses belajar tidak terbatas pada satu- pembelajaran satu-satu. Alih-alih berfokus pada satu komponen keberadaan manusia, layanan pembelajaran pendidikan di luar sekolah menggabungkan berbagai aspek kehidupan masyarakat. Ada empat cara lagi Pusat Kegiatan Belajar Masyarakat (PKBM) dapat menjadi lembaga pembelajaran rakyat, dan semuanya berkisar pada kemampuannya untuk berkolaborasi secara kolaboratif dan sinergis dengan berbagai lembaga lain di masyarakat. Sebagai sarana untuk menyadarkan masyarakat, telah dibentuk Pusat Kegiatan Belajar Masyarakat (PKBM). Sebagai titik akhir, Pusat Kegiatan Belajar Masyarakat (PKBM) menitikberatkan pada peran orang belajar sebagai siswa yang harus aktif terlibat dalam kegiatan belajar bagi dirinya dan masyarakatnya. sendiri, masyarakat dan lembaga Pusat Kegiatan Belajar Masyarakat (PKBM) itu sendiri, dan akhirnya menjadi lembaga milik masyarakat dan didirikan dengan tujuan mencerdaskan kehidupan masyarakat, hadirnya Pusat Kegiatan Belajar Masyarakat (PKBM) memiliki potensi untuk memberdayakan masyarakat secara holistik dalam arti mampu membantu kelompok yang terpinggirkan agar memiliki potensi yang seimbang dengan memanfaatkan kelompok lain yang lebih terjamin kehidupan sosial ekonominya, dengan memberikan pelayanan pendidikan yang terjangkau sebagai hasil, dapat dinaikkan statusnya, hak-haknya baik sosial maupun ekonomi.

Pusat Kegiatan Belajar Masyarakat (PKBM) menangani sejumlah masalah internal, antara lain kurangnya kapasitas Pusat Kegiatan Belajar Masyarakat (PKBM) untuk mengembangkan program pendidikan setelah sekolah yang memenuhi kebutuhan lokal, sebagian besar PKBM melaksanakan program yang disponsori pemerintah, dan tingkat pencapaian kualitas minimal pembelajaran masyarakat. Pusat Kegiatan Belajar Masyarakat (PKBM) Rumah Kaca Kabupaten Deli Serdang dijadikan sebagai tempat ditemukannya telepon genggam PKBM ini. Mengabaikan masalah ini dapat memiliki konsekuensi jangka panjang bagi universitas. Semua lapisan masyarakat telah memperhatikan apa yang terjadi di Pusat Kegiatan Belajar Masyarakat (PKBM), serta para pendidik dan tenaga kependidikan yang berpartisipasi. Organisasi menggunakan perencanaan strategis sebagai aktivitas manajemen untuk menentukan prioritas, memfokuskan energi dan sumber daya, dan meningkatkan kinerja operasional. Selain itu, perencanaan strategis memastikan bahwa karyawan dan pemangku kepentingan lainnya bekerja menuju tujuan dan 
standar bersama untuk hasil yang diinginkan sementara juga memungkinkan fleksibilitas dalam menanggapi perubahan. Sebagai hasil dari disiplin ini, organisasi dapat mengidentifikasi siapa yang dilayaninya, apa yang dilakukannya dan mengapa harus melakukannya. Agar sebuah organisasi berhasil, ia perlu tahu ke mana ia pergi dan apa yang perlu dilakukan untuk sampai ke sana, tetapi ia juga perlu tahu bagaimana ia akan tahu apakah ia berhasil.

\section{Metode}

\subsection{Pendekatan Penelitian}

Metode kualitatif digunakan dalam penelitian ini. Hal ini disebabkan fakta bahwa informasi yang dikumpulkan adalah dalam bentuk data kualitatif daripada kuantitatif. Berdasarkan individu dan kondisi yang diamati, penelitian kualitatif menghasilkan data naratif dalam bentuk istilah tertulis atau lisan [2]. Namun, juga dapat digunakan untuk menyelidiki dan menjelaskan suatu kejadian atau fenomena. Penelitian ini bersifat naratif, sehingga akan merinci beberapa variabel yang terkait dengan masalah. Gambar dan detail mengenai Perencanaan Strategi Pemasaran untuk Meningkatkan Pengembangan Bisnis dapat diakses dalam hal ini. Rumah Hijau Kabupaten Deli Serdang, Pusat Kegiatan Belajar Masyarakat (PKBM) Sumatera Utara.

\subsection{Lokasi Penelitian}

Penelitian ini dilakukan pada Pusat Kegiatan Belajar Masyarakat PKBM Rumah Hijau Kabupaten Deli Serdang Sumatera Utara, Jl. Lintas Sumatera No. 220 Pagar Jati Kecamatan Lubuk Pakam, Kabupaten Deli Serdang, Sumatera Utara - 20551.

\subsection{Sampel}

Sampel dalam penelitian ini adalah Kepala Sekolah Pusat Kegiatan Belajar Masyarakat (PKBM) Rumah Hijau dan guru yang mengajar di sekolah tersebut atau semua tenaga kependidikan di sekolah tersebut, serta yang dianggap perlu terlibat secara langsung maupun tidak langsung Pusat Kegiatan Belajar Masyarakat (PKBM) tersebut. Sementara yang menjadi informasi kunci adalah Kepala Sekolah yang menjabat di Pusat Kegiatan Belajar Masyarakat (PKBM) Rumah Hijau itu sendiri.

\subsection{Metode Pengumpulan Data}

Wawancara digunakan oleh peneliti untuk mengumpulkan informasi. Menggunakan informan sebagai sumber data, peneliti melakukan wawancara tatap muka di mana pertanyaan dan tanggapan dipertukarkan. Wawancara dilakukan dengan menggunakan pedoman wawancara tidak terstruktur, yang secara sederhana menguraikan pertanyaan-pertanyaan yang akan ditanyakan selama wawancara. Ada beberapa cara wawancara dilakukan: satu metode menggunakan Kepala PKBM (serta guru, pengelola, dan/atau tutor lainnya) untuk menggali atau mencari liputan secara lisan, sedangkan metode lain adalah dengan melakukan wawancara secara lisan. cara yang tidak mengganggu kegiatan peneliti dan pekerjaan

yang ada. Peneliti melakukan pertanyaan sinkron dengan menggunakan garis besar wawancara yang telah disiapkan, namun dalam praktiknya, mereka menanyakan dan menyelidiki topik secara mendalam berdasarkan liputan yang dikomunikasikan oleh pewawancara. Sebagai bagian dari penelitian ini, metode wawancara digunakan untuk mengetahui pengelolaan strategi bisnis PKBM, sedangkan cakupan pengelola atau tutor digunakan untuk meningkatkan cakupan pimpinannya, PKBM. Sebuah perekam suara digunakan oleh peneliti untuk menangkap semua informasi yang diberikan selama wawancara, sehingga lebih mudah bagi mereka untuk mendapatkan cakupan yang lengkap. Selain itu, peneliti menuliskan informasi apa pun yang sangat penting untuk penelitian mereka dan menyimpannya dalam arsip secara permanen.

\subsection{Teknik Analisis Data}

Teknik analisis data pada model ini terdiri dari beberapa komponen yang saling berhubungan, pengumpulan data, reduksi, penyajian dan penarikan kesimpulan dan verifikasi. Aktivitas dalam analisis JCRS (Journal of Community Research and Service), 6(1), 2022 
data kualitatif dilakukan secara interaktif dan berlangsung secara terus menerus sampai tuntas sehingga datanya sudah jenuh. Keempat komponen merupakan siklus yang berlangsung secara terus menerus, sebagai berikut:

\section{Pengumpulan Data}

Dalam melakukan pengumpulan data pada penelitian ini, peneliti menggunakan teknik wawancara yang dilakukan di Pusat Kegiatan Belajar Masayarakat (PKBM) Rumah Hijau Kabupaten Deli Serdang Sumatera Utara. Wawancara direkam dengan alat perekam dan mencatat semua informasi yang dibutuhkan, wawancara dilakukan kepada Kepala PKBM, Guru, pengelola atau tutor.

\section{Reduksi Data}

Reduksi data merupakan analisis yang berfungsi menajamkan, menggolongkan, mengarahkan, membuang yang tidak perlu, dan mengorganisasikan data sedemikian rupa sehingga diperoleh kesimpulan dari data penelitian tersebut. Dalam reduksi data tersebut mengandung unsur, sebagai berikut:

a) Proses pemilihan data atas dasar tingkat relevansi dan kaitannya dengan setiap kelompok data.

b) Menyusun data dalam satuan jenis.

c) Membuat koding data sesuai dengan kisi-kisi kerja penelitian.

d) Memfokuskan, menyederhanakan, dan mentransfer data kasar ke catatan lapangan.

Dari data yang telah diperoleh selama melakukan penelitian dikelompokkan berdasarkan sumber informan, dari hasil wawancara yang telah direkam kemudian dipindahkan ke bentuk tulisan agar mudah dalam menganalisis dan memahami maksud dari informan. Untuk mempermudah dalam menyampaikan atau memaparkan dalam laporan maka data yang ada di kelompokkan dan disederhanakan.

\section{Penyajian Data}

Penyajian data dibatasi sebagai kumpulan informasi tersusun yang memberikan kemungkinan adanya penarikan kesimpulan dan pengambilan tindakan. Dalam penyajian data ini kecenderungan mengarah pada penyederhanaan data kompleks kedalam kesatuan bentuk yang sederhana dan selektif sehingga mudah dipahami. Tahap penyajian data, prosesnya adalah dari konsep penyajian data yang telah dibuat data yang ada dimasukkan sesuai dengan pembahasannya.

\section{Penarikan Kesimpulan}

Setelah dilakukan pengumpulan data, reduksi data dan penyajian data, langkah berikutnya adalah melakukan penarikan kesimpulan dan verifikasi dengan tujuan menjawab rumusan masalah. Pada langkah verifikasi, peneliti hendaknya menuju kearah kesimpulan yang sifatnya terbuka, peneliti juga masih bisa menerima masukan dari peneliti lain. Penarikan kesimpulan dan verifikasi diuraikan secara detail mengenai gambar permasalahan yang ada di lapangan serta solusi konkrit yang diberikan.

\section{Hasil dan Pembahasan}

Pusat Manajemen Pendidikan untuk Pusat Kegiatan Pembelajaran Masyarakat (PKBM) adalah tempat di mana salah satu institusi berfungsi sebagai forum untuk memberikan peluang penuh kepada seluruh masyarakat untuk melatih masyarakat untuk mandiri dan kualitas kehidupan masyarakat meningkat, dan pengembangan masyarakat meningkat, dan pengembangan masyarakat meningkat, dan pengembangan masyarakat meningkat, dan pengembangan masyarakat meningkat, dan pengembangan masyarakat meningkat, dan pengembangan Komunitas.

\subsection{Perencanaan dalam Pusat Kegiatan Belajar Masyarakat (PKBM)}

Kegiatan yang direncanakan dimaksudkan untuk membantu dalam membuat keputusan yang sesuai dengan tujuan utama perusahaan. Perencanaan strategis terutama berkaitan dengan memastikan bahwa operasi perusahaan seefektif dan seefisien mungkin. Akibatnya, perusahaan akan lebih mudah mengenali dan memperbaiki setiap masalah yang mungkin muncul di masa depan, sehingga dapat berjalan lebih lancar. Terlihat pentingnya perencanaan di pusat kegiatan belajar masyarakat, di mana tujuan dibuat dan tindakan dilakukan untuk mencapainya, serta tahapan atau sumber daya yang digunakan untuk menentukan apa yang dapat diharapkan untuk dicapai di sana. Rumah Hijau, direktur Pusat Kegiatan Belajar Masyarakat (PKBM), mengatakan kepada peneliti bahwa: "Dalam mengembangkan Pusat 
Kegiatan Belajar Masyarakat (PKBM), pada awalnya direncanakan dengan langkah-langkah, seperti penguatan sumber daya manusia. Agar masyarakat dapat memahami bagaimana Pusat Kegiatan Belajar Masyarakat (PKBM) diimplementasikan di Green House, penting untuk merencanakan pembenahan sumber daya manusia.Ternyata juga bahwa mempersiapkan kegiatan pembelajaran memerlukan perencanaan sumber daya manusia.Untuk lebih memahami bagaimana pembelajaran masyarakat kegiatan dilaksanakan, masyarakat dilaksanakan dengan langkah-langkah sumber daya manusia. Kegiatan yang direncanakan oleh pengajar atau pengelola Pusat Kegiatan Belajar Masyarakat (PKBM) merupakan salah satu cara untuk membantu mengembangkan sumber daya manusia agar dapat mencapai tujuan yang diinginkan. perencanaan dari pihak ketua Pusat Kegiatan Belajar, dapat dikatakan bahwa Pusat Kegiatan Belajar Masyarakat (PKBM) merupakan dan kepala Pusat Kegiatan Belajar Masyarakat (PKBM) berencana untuk mencapai visi dan misi lembaga melalui upaya para pembina dan pengurus PKBM serta pihak-pihak yang harus direncanakan oleh kepala Pusat Kegiatan Belajar Masyarakat (PKBM). Dapat dikatakan bahwa Pusat Kegiatan Belajar Masyarakat (PKBM) didasarkan pada suatu proses perencanaan untuk mencapai pengelolaan Pusat Kegiatan Belajar Masyarakat (PKBM) yang baik. Hal ini karena perencanaan merupakan fungsi utama dalam mencapai tujuan pendidikan yang sejalan dengan tujuan yang telah ditetapkan. Setelah wawancara, peneliti dapat menyimpulkan berdasarkan temuan mereka bahwa Pusat Kegiatan Belajar Masyarakat (Perencanaan PKBM) Rumah Kaca telah selesai sebelum prosedur yang diperlukan untuk sumber daya manusia diambil untuk memastikan pemahaman publik tentang apa yang terjadi di dalam. Alhasil, perencanaan pusat pembelajaran masyarakat Green House dilakukan sesuai dengan tujuan sarana atau prasarana. Pusat Pembelajaran Masyarakat (PKBM) yang mengembangkan Pusat Kegiatan Belajar Masyarakat (PKBM), seperti pengurusnya dan tutor yang telah dibina oleh ketuanya sesuai dengan visi dan misi Pusat Kegiatan Belajar (PKBM), berikut ini. Pencapaian hasil yang diinginkan membutuhkan bantuan dari Komunitas Rumah Kaca (PKBM).

\subsection{Pengorganisasian dalam Pusat Kegiatan Belajar Masyarakat (PKBM)}

Fungsi organisasi adalah kegiatan penyiapan dan pengerahan sumber daya yang teridentifikasi, peninjauan atau pengelolaan sumber daya yang akan digunakan sesuai dengan kebutuhan atau tuntutan program kegiatan. Sumber daya manusia, organisasi juga merupakan kegiatan menghimpun dan mengorganisasikan sumber daya manusia agar kegiatan untuk mencapai tujuan yang telah ditetapkan dapat dilakukan secara efektif dan efisien di Pusat Kegiatan Belajar Masyarakat (PKBM) Rumah Kaca yang menyatakan bahwa: "Dalam Pusat Kegiatan Belajar Masyarakat (PKBM), untuk kelompok ada 3 (tiga) jurusan yang ditawarkan, yaitu menjahit, kecantikan dan IT. Dalam penentuan tugas Pusat Kegiatan Belajar Masyarakat (PKBM) yaitu pengurus atau tutor yang melakukan kegiatan atau pembelajaran kepada peserta kemudian pengurus harus membuahi program langkah-langkah sesuai visi dan misi seperti 5 (lima) tahun kemudian dan dimana tutor yang memberikan kerangka pembelajaran atau berdasarkan silabus, yaitu apabila dalam melakukan kegiatan atau pembelajaran kepada peserta tutor dan pengurus membuahi langkah sesuai visi dan misi yang ada di Pusat Kegiatan Belajar Masyarakat (PKBM) Rumah Hijau seperti tutor memberi bahan ajar kepada peserta belajar dan pengurus Pusat Kegiatan Belajar Masyarakat (PKBM) yaitu mendukung, memantau menindak lanjuti dan memecahkan masalah yang ada pada kegiatan belajar. Untuk mengambil keputusan dalam organisasi atau kelompok maka dilakukan melalui musyawarah karena dalam melakukan segala sesuatu atau keputusan harus diadakan pertemuan dari setiap bagian yang terlibat dalam pusat kegiatan belajar masyarakat agar mendapat titik terang atau temu dari setiap pendapat yang dikeluarkan, hasil tersebut dijelaskan bahwa dalam melakukan segala kegiatan diadakan pertemuan dari semua bagian pengurus Pusat Kegiatan Belajar Masyarakat (PKBM) agar dapat menemukan pendapat masing masing sehingga dapat menemukan kesepakatan bersama agar mencapai tujuan yang diinginkan. Pengaturan aktifitas setiap anggota Pusat Kegiatan Belajar Masyarakat (PKBM) untuk mencapai tujuan dilakukan dengan fungsi manajemen yang dimana sesuai dengan visi misi pusat kegiatan belajar masyarakat kemudian pengorganisasian membentuk organisasi yang terdiri dari sumber daya manusia yang akan mendayagunakan sumber daya yang ada untuk melaksanakan kegiatan sesuai yang direncanakan sebelumnya". Berdasarkan hasil wawancara di atas, dapat dikemukakan bahwa pengorganisasian pusat kegiatan belajar masyarakat berdasarkan sumber daya manusia yang sudah direncanakan sebelumnya dalam kegiatan belajar sehingga untuk mencapai tujuan pusat kegiatan belajar sesuai dengan visi dan misi yang ada dipusat PKBM Rumah Hijau. 


\subsection{Pelaksanaan dalam Pusat Kegiatan Belajar Masyarakat (PKBM)}

Fungsi pelaksanaan dalam manajemen Pusat Kegiatan Belajar Masyarakat (PKBM) tidak lain merupakan upaya untuk menjadikan perencanaan menjadi kenyataan dengan melalui pengorganisasian yang baik, pelaksanaan pusat kegiatan belajar masyarakat telah terlaksana dengan baik meskipun apa yang telah direncanakan tidak semua terealisasi karena sebagian sumber daya manusia dilaksanakan sendiri dan sebagian juga berkerja sama dengan forum Pusat Kegiatan Belajar Masyarakat (PKBM). Untuk mengetahui sejauh mana pelaksanaan pusat kegiatan belajar masyarakat, maka berikut ini hasil wawancara yang dilakukan peneliti dengan Pusat Kegiatan Belajar Masyarakat (PKBM) Rumah Hijau yang mengatakan bahwa: "Metode yang dilakukan dalam proses pelaksanaan pusat kegiatan belajar masyarakat yaitu dimana metode pembelajaran disesuaikan dengan situasi dan kondisi peserta belajar, yang dimana ada 4 (empat) empat metode pembelajaran yaitu metode tatap muka, during, metode tutorial, dan metode belajar mandiri. Proses pelaksanaan Pusat Kegiatan Belajar Masyarakat (PKBM) dilakukan dengan metode tatap muka seperti, peserta didik datang kelembaga dengan bertemu langsung dengan tutor dengan jadwal yang telah ditentukan yaitu dengan 2 atau 3 hari tatap muka layaknya sekolah formal, kedua metode during dilakukan 1 hari setiap minggunya guna membiasakan proses pembelajaran bila nantinya terhalang oleh Virus Covid dll, metode ketiga metode tutorial yaitu peserta didik melakukan tanya jawab dengan tutor tentang materi pelajaran yang belum diketahui pada modul, tutorial metode ini juga dapat dilakukan melalui online dengan menggunakan media sosial atau dengan melakukan tatap muka secara langsung tapi tidak didalam kelas dengan prinsip fleksibel sehingga peserta nyaman, menyesuaikan atau merupakan suatu penghargaan pada peserta didik untuk mau belajar, dan kemudian metode keempat yaitu metode belajar mandiri yaitu para peserta harus mempelajari materi tanpa harus bantuan dari tutor, pembelajaran mandiri dilakukan ditempat masing masing peserta. Dan selanjutnya akan dibahas pada pertemuan tatap muka. Dalam hal-hal yang perlu diperhatikan dalam pelaksanaan Pusat Kegiatan Belajar Masyarakat (PKBM) yaitu dengan pengembangan ilmu pengetahuan kemudian memotivasi masyarakat, melaksanakan proses belajar mengajar, dan memulai proses dan hasil kegiatan mengajar secara berskala". Berdasarkan hasil wawancara di atas, yang perlu diperhatikan pada proses pelaksanaan kegiatan belajar yaitu ilmu pada peserta, untuk dapat memulai proses dan hasil untuk mengembangkan ilmu pengetahuan. Pelaksanaan Pusat Kegiatan Belajar Masyarakat (PKBM) dilakukan setiap proses pembelajaran dan dimana pembelajarannya setiap Senin sampai dengan Jumat, Pusat Kegiatan Belajar Masyarakat (PKBM) dilaksanakan Lembag Rumah Hijau Jl. Lintas Sumatera No. 220 Pagar Jati Deli Serdang.

\subsection{Perencanaan dalam Pusat Kegiatan Belajar Masyarakat (PKBM)}

Pengawasan merupakan salah satu kunci keberhasilan dari keseluruhan proses pendidikan, pengawasan adalah kegiatan pengawasan yang bertujuan untuk menentukan harapan nyata yang akan terwujud atas apa yang terjadi, karena semua fungsi yang didahulukan baik perencanaan, pengorganisasian, pelaksanaan tidak akan efektif tanpa adanya fungsi pengawasan. Untuk memperoleh informasi lebih lanjut peneliti kembali melakukan wawancara mengenai pengawasan terhadap Pusat Kegiatan Belajar Masyarakat (PKBM) Green House dimana beliau menyatakan bahwa: "Di dalam Pusat Kegiatan Belajar Masyarakat (PKBM) untuk melakukan pengawasan diperlukan laporan-laporan yang bersifat dilaporkan setiap saat ke Dinas Pendidikan Deli Serdang, sebagai evaluasi kinerja laporan salah satunya persentase kehadiran siswa, melalui supervisi yang dilakukan oleh Pusat Kegiatan Belajar Masyarakat (PKBM) yang sangat tersusun. Pusat Kegiatan Belajar masyarakat (PKBM) adapun yang ikut berpartisipasi dalam kegiatan belajar oleh pengurus Pusat Kegiatan Belajar masyarakat (PKBM) itu sendiri, dan untuk ujian paket A, B, dan C itu dari Dinas Pendidikan Deli Serdang. Dalam ujian atau evaluasi tahap akhir dilakukan untuk mengukur apakah pelaksanaan sudah sesuai dengan tujuan dan rencana yang sudah ditentukan dan ada arahan sebelum melaksanaan ujian”. Berdasarkan hasil wawancara di atas menunjukkan bahwa pada tahap pengevaluasian diukur dengan tujuan rencana dan arahan yang dilakukan sebelum ujian yaitu memberikan kisi-kisi dan memotivasi peserta belajar agar bersemengat dalam melakukan ujian akhir dari kegiatan belajar. Berdasarkan hasil wawancara yang dilakukan peneliti dengan pelapor, Pusat Kegiatan Belajar Masyarakat (PKBM) harus melapor ke dinas pendidikan di Deli Serdang untuk mengetahui kehadiran siswa dan kemudian juga mengawasi mereka yang mengikuti pembelajaran. kegiatan. oleh pengelola Pusat Kegiatan Belajar Masyarakat (PKBM). dan untuk UAS Paket A, B dan C Dinas Pendidikan Makassar, maka sebelum melanjutkan ke ujian akhir pada peserta diberikan bimbingan bagaimana memotivasi dan memberikan kisi-kisi agar peserta 
bersemangat mengikuti ujian. Keuntungan bagi peserta adalah memiliki hak yang sama dengan pemegang ijazah pendidikan formal, seperti ijazah yang dikeluarkan negara yang dapat digunakan untuk melanjutkan ke jenjang yang lebih tinggi atau untuk kebutuhan 'usaha'. Pusat Kegiatan Belajar Masyarakat (PKBM) juga memiliki bekal di bidang keterampilan khusus yang harus disesuaikan agar mampu mempersiapkan pesertanya menghadapi dunia. pekerjaan atau dunia bisnis.

\subsection{Faktor Pendukung dan Penghambat Pusat Kegiatan Belajar Masyarakat (PKBM) Rumah Hijau}

\section{Faktor Pendukung}

Faktor yang menjadi pendukung dalam manajemen pendidikan kesetaraan Pusat Kegiatan Belajar Masyarakat (PKBM) Rumah Hijau adalah sebagai berikut:

\section{a) Sumber Daya Manusia}

Keberhasilan suatu organisasi mencapai tujuannya salah satunya ditentukan oleh ketersediaan sumber daya manusia yang cukup, dalam hal ini pegawai atau aparaturnya dalam organisasi tersebut. Sumber daya manusia yang dimaksud disini berkaitan dengan kuantitas dan kualitas berupa kemampuan pengurus Pusat Kegiatan Belajar Masyarakat (PKBM) dalam manajemen pendidikan kesetaran Pusat Kegiatan Belajar Masyarakat (PKBM) Rumah Hijau. Kemampuan sumber daya yang dimiliki Pusat Kegiatan Belajar Masyarakat (PKBM) terdiri dari kemampuan untuk merencanakan kejelasan kepada masyarakat. Hasil Wawancara dengan Pusat Kegiatan Belajar Masyarakat (PKBM) Rumah Hijau, sebagai berikut: "Kualitas sumber daya manusia yang dimiliki oleh Pusat Kegiatan Belajar Masyarakat (PKBM) sudah memadai pada umumnya, hal ini karena secara formal pendidikan mereka rata-rata sarjana lengkap Strata Satu (S1) sehingga memiliki pengalaman dan masa kerja yang cukup lama. Sumber Daya Manusia yang dimiliki manajemen Pusat Kegiatan Belajar Masyarakat (PKBM) memiliki kemampuan dalam menjalankan tugas dan memiliki kemampuan disiplin pada kegiatan atau pembelajaran karena menjalankan sesuai masing masing dan mereka juga berpengalaman". Berdasarkan hasil wawancara di atas menunjukkan bahwa manajemen Pusat Kegiatan Belajar Masyarakat (PKBM) memiliki sumber daya pengurus cukup memadai karena memiliki kualifikasi sarjana. Kemampuan yang dimiliki oleh sumber daya pengurus antara lain:

1) Kemampuan dalam merencanakan pusat kegiatan.

2) Kemampuan operasional dan tugas khusus dalam pelayanan publik.

3) Kemampuan melakukan pengembangan ilmu pengetahuan.

4) Kemampuan dalam mengelola SDM dan Umum.

\section{b) Tutor (Pengajar)}

Salah satu faktor penting dalam pengelolaan Pusat Kegiatan Belajar Masyarakat (PKBM) adalah keberadaan tutor untuk kegiatan pembelajaran karena dalam kegiatan pembelajaran utama yang bertujuan memberikan pengetahuan kepada peserta, tutor harus menyediakan siswa atau bahan belajar sesuai dengan jadwal yang telah ditentukan. dikemukakan oleh Pusat Kegiatan Belajar Masyarakat (PKBM) Rumah Kaca, sebagai berikut: "Salah satu sarana penunjang kegiatan pembelajaran adalah melalui tutor yang harus memberikan ilmu kepada siswa agar dapat mengembangkan ilmu dari pembelajaran Partisipatif yang bersifat akademik, sehingga belajar mandiri maupun berkelompok dapat dilakukan dengan lancar dan selain itu para tutor juga dibekali dengan pengalaman dan pengetahuan dimana para tutor juga harus mengungguli pesertanya. (S2)". Dalam pengelolaan pusat kegiatan belajar masyarakat ada dua, yaitu sumber daya manusia yang didukung oleh pengalaman dan yang kedua adalah untuk memperlancar kegiatan belajar belajar atau untuk mengembangkan ilmu pengetahuan.

\section{Faktor Penghambat}

Adapun faktor yang menjadi penghambat dalam manajemen Pusat Kegiatan Belajar Masyarakat (PKBM) Rumah Hijau, sebagai berikut: 


\section{a) Konsep Peserta Belajar}

Hal ini menjadi tantangan besar bagi pengelola dan pembina Pusat Kegiatan Belajar Masyarakat Rumah Kaca (PKBM) untuk memperkenalkan konsep belajar sepanjang hayat agar peserta didik dapat belajar lebih banyak tentang kegiatan belajar. Hasil wawancara dengan Pusat Kegiatan Belajar Masyarakat (PKBM) Rumah Hijau adalah sebagai berikut: "Masih sedikit siswa yang bisa berkonsentrasi belajar, dan ada juga siswa yang tidak bisa berkonsentrasi pada kegiatan belajar seperti chatting dan lokasi peserta saat pembelajaran. Tergantung hasilnya, mereka mengabaikan prosesnya saja. Ini sangat mengecewakan bagi pengajar. Dari hasil wawancara dijelaskan bahwa peserta kegiatan pembelajaran tidak mengabaikan proses kegiatan pembelajaran tetapi hanya mempertimbangkan hasil dan tidak cukup berkonsentrasi pada pengetahuan.

\section{Kesimpulan}

Berdasarkan hasil pembahasan yang telah diuraikan mengenai Analisis Perencanaan Strategi Dalam Meningkatkan Pengembangan Usaha Pusat Belajar Masyarakat (PKBM) Rumah Hijau Kabupaten Deli Serdang Sumatera Utara, maka dapat ditarik kesimpulan berdasarkan fungsi-fungsi manajemen yangmenjadi fokus penelitian yang meliputi:

1. Fungsi perencanaan, perencanaan pada Pusat Kegiatan Belajar Masyarakat (PKBM) Rumah Hijau sudah berjalan baik, hal ini terlihat bahwa perencanaan Pusat Kegiatan Belajar Masyarakat (PKBM) berjalan sesuai dengan perencanaan yang telah melakukan langkah langkah sumber daya manusia agar memperjelas masyarakat untuk mempermudah mengetahui tentang pusat kegiatan belajar.

2. Fungsi Pengorganisasian, pengorganisasian pada Pusat Kegiatan Belajar Masyarakat (PKBM) Rumah Hijau sudah berjalan dengan baik, hal ini dapat dikemukakan bahwa Pusat Kegiatan Belajar Masyarakat (PKBM) apabila sebelum mengadakan kegiatan pembelajaran diadakan musyawarah dalam bidang yang terlibat pada kegiatan pembelajaran agar tercapainya tujuan sesuai visi dan misi.

3. Fungsi pelaksanaan, pelaksanaan pada Pusat Kegiatan Belajar Masyarakat (PKBM) Rumah Hijau sudah berjalan dengan baik, hal ini dapat dikemukakan bahwa proses dalam melaksanakan pembelajaran yang dilakukan bisa dimana saja karena tidak mesti harus berada dalam ruangan dan pelaksanakan kegiatan belajar dijadwalkan pada hari Senin sampai dengan Jumat.

4. Fungsi pengawasan, pengawasan pada Pusat Kegiatan Belajar Masyarakat (PKBM) Rumah Hijau dikategorikan baik karena yang melakukan setiap pengawasan perlu laporan yang setiap saat dilaporkan kepada Dinas Pendidikan Deli Serdang dan yang ikut berpartisipasi dalam kegiatan belajar oleh pengurus Pusat Kegiatan Belajar Masyarakat (PKBM) itu sendiri, dan untuk pengawas ujian paket A, B, dan C itu dari Dinas Pendidikan.

5. Dalam Pendidikan Pusat Kegiatan Belajar Masyarakat (PKBM) Rumah Hijau ada beberapa yang menjadi faktor pendukung dan penghambat yaitu tersedianya sumber daya manusia dan tutor (pengajar) pada Pusat Kegiatan Belajar Masyarakat (PKBM) Rumah Hijau sedangkan Faktor Penghambatnya yaitu konsep peserta belajar yang masih banyak belum fokus dalam pembelajaran berlangsung.

\section{Referensi}

[1] Yulaelawati E. Kurikulum dan Pembelajaran Filosofi Teori dan Aplikasi. Bandung: PT Pakar Karya; 2010

[2] Tohirin, Metode Penelitian Kualitatif dalam Pendidikan dan Bimbingan Konseling. (Jakarta: Raja Grafindo Persada). hal.2. 